\title{
Transformational Leadership Job Satisfaction's Relationship with Innovativeness in Elementary Schools
}

\author{
Necati ÇOBANOĞLU1
}

\begin{abstract}
Situations that are changing over time force organizations to change just as they force individuals. Transformational leaders are needed for the changes to be made in organizations in a time and in a required way. Transformational leaders provide the change needed by organizations while having various effects on the employees. This study aims to examine the effect of transformational leadership on teachers' job satisfaction and innovative behavior. The research is a study based on a correlational survey model. The data of the research were collected in official elementary schools in the province of Malatya in 2020-2021 academic year. Correlation analysis and structural equation modelling were used to analyze the data. According to the results of the study, there is a positive, significant and moderate relationship between the principal's transformational leadership and teachers' job satisfaction and innovative behavior. Moreover, transformational leadership predicts teachers' job satisfaction and innovative behavior.
\end{abstract}

Keywords: Transformational leadership, Job satisfaction, Innovativeness, Elementary school

\section{İlköğretim Okullarında Dönüşümcü Liderlik ve İş Doyumunun Yenilikçilik ile İlişkisi}

Öz: Zaman içerisinde değişen durumlar bireyleri değişime zorladığı gibi örgütleri de değişime zorlamaktadır. Örgütlerde değişimin gerektiği zamanda ve gerektiği gibi yapılabilmesi için dönüşümcü liderlere ihtiyaç duyulmaktadır. Dönüşümcü liderler bir yandan örgütün ihtiyaç duyduğu değişimi sağlarken diğer yandan çalışanlar üzerinde çeşitli etkiler bırakmaktadır. Bu araştırmada dönüşümcü liderliğin öğretmenlerin iş doyumuna ve yenilikçi davranışına etkisinin incelenmesi amaçlanmıştır. Araştırma, ilişkisel tarama modelinde bir çalışmadır. Araştırmanın verileri 2020-2021 eğitim öğretim yılında, Malatya ilinde ve resmi ilkokullarda toplanmıştır. Verilerin analizi için korelasyon analizi ve yapısal eşitlik modellemesi yapılmıştır. Araştırmanın sonuçlarına göre, ilkokullarda dönüşümcü liderlik, iş doyumu ve yenilikçi davranış düzeyi "genellikle yüksek"tir. Müdürün dönüşümcü liderliği ile öğretmenlerin iş doyumu ve yenilikçi davranışları arasında pozitif yönde anlamlı ve orta düzeyde bir ilişki vardır. Ayrıca dönüşümcü liderlik öğretmenlerin iş doyumunu ve yenilikçi davranmasını yordamaktadır.

Anahtar Sözcükler: Dönüşümcü liderlik, İş doyumu, Yenilikçilik, İlkokul 
Technological advancements of the last century have greatly increased the mechanization in business environments. However, despite all the advancements of technology, human beings as the most fundamental element in the working environment have not lost its importance, in fact, it has increased its importance even more. Emotions, thoughts and behaviours in the working environment have been examined through scientific studies (Tanhan, 2020). It has been seen in many studies that human beings should be approached differently than machines and that their satisfaction positively and dissatisfactions negatively affect their work (Büyükgöze and Büyükgöze-Kavas, 2016; Güney, 2017; Hechanova, Alampay and Franco, 2006; Özgen and Yalçın, 2011). In Ecological Systems Theory, it is stated that the individual is affected by his immediate environment (family, work and social environment) and different characteristics of the society he lives in. In this framework, employees are affected by their organizations, the social, economic and administrative structure of their organizations, their colleagues and managers (Bronfenbrenner, 1979, Tanhan, 2020).

One of the emotions of employees about work is job satisfaction. It is thought that job satisfaction provides individually psychological satisfaction for the employees and contributes to the organization. Based on this thought, we're aiming to discuss job satisfaction as a reason variable and to examine the relationship between job satisfaction and innovativeness of the employees. Employees who fully perform the tasks defined for them are considered valuable from the viewpoint of the organizations. Even more valuable employees in these organizations are those who contribute to the organization beyond their own job descriptions. One of the most important contributions employees can make to the organization is to develop new methods and practices that will contribute positively to the organization. In addition, these contributions can make the organization stand out in its field and get ahead of its competitors.

People's feelings, thoughts and actions change due to various wants and needs. As time and conditions change, the needs of organizations also change. It is considered important that these naturally changing interests and needs are taken into account by educational organizations and managed. Can transformational leaders break employee resistance to change? Can it influence employees with new and future-oriented ideas? Can it increase the innovativeness and job satisfaction of the employees by taking into account their feelings and thoughts? Within the framework of these questions, it is aimed to examine the relationship between transformational leadership in educational organizations and teachers' job satisfaction and innovativeness.

\section{Conceptual Framework}

\section{Transformational Leadership}

The scientific discussion of transformational leadership was first made by Burns (1978). In this discussion, transformational leadership was defined as recognizing employees' interests, desires, needs and emotions to use them in achieving motivation (Karip, 1998). In later studies, it was stated that transformational leadership is a suitable type of leadership to convince employees to change, transform and progress, to create a high motivation, to create awareness and organizational commitment among the employees (Arago'n-Correa, Garcı'a-Morales and Cordo'n-Pozo, 2007; Bass, 1998; Mc Cleskey, 2014; Şahin, 2004).

Transformational leadership provides the employees with vision and inspiration as being a suitable role model for them. It ensures that the targets of the organization are recognized by the employees. It recommends the employees create different solutions by bringing an intellectual perspective to the problems they encounter. It supports, coaches and encourages employees in solving the problems they encounter. It prepares employees emotionally and ensures that they have high expectations for success (Göksoy, Torlak and Uğuz, 2019; Kiriş and Aslan, 2019).

One of the aspects of transformational leadership is that employees have the right vision. For the right vision, transformational leaders act as proper role models for their employees. They motivate them with their future-looking perspectives and expect them to lead. To blaze the trail for the organizational transformation and to inspire the employees, all employees have listened carefully and a change vision is worked to be created among all the employees (İşcan, 2002; Kiriş and Aslan, 2019; Mc Cleskey, 2014). Another aspect of transformational leadership is to lead and be a role model to make employees adopt organizational / group 
targets. Individual beliefs and efforts of the leader or some employees alone are not sufficient for transformations in organizations. Organizational transformation can occur through all the employees' beliefs towards the aim and making it real (Altın, 2019). It is considered important to ensure this unity among employees for transformational leadership. Intellectual encouragement for employees is another aspect of transformational leadership. Intellectual encouragement means convincing employees that they are capable of solving the problems they face (Coad and Berry, 1998). It is seen as encouraging and motivating them to solve the difficulties with different and new methods (Glad and Blanton, 1997). Showing interest to employees as another aspect of transformational leadership is the interest and value offered by the leader to employees in a way that they will feel special. It is providing opportunities and guidance for employees to improve themselves (Akbolat, Işık and Yılmaz, 2013; Kiriş and Aslan, 2019). Another aspect of transformational leadership is that the leader expects high success from his employees and informs them about this expectation. Organizational transformation can occur when employees believe that they can do more than they have done in their previous works (Dublin, 2001).

\section{Job Satisfaction}

Job satisfaction is a theme that has been discussed since the beginning of the 20th century. This issue has been discussed based on the idea that people, unlike machines, add their emotions to their work, and they are affected by emotional experiences in the work environment while affecting this environment as well (Eğinli, 2009; Güney, 2017; Taş and Önder, 2010). Employees who are satisfied with the work environment and with the work they do, and also who enjoy that work achieve more satisfaction. The level of satisfaction of employees that are working in the work environment for long hours every day is quite important. Many studies in the literature have shown that job satisfaction has positive effects such as success, self-efficacy, positive psychological capital, psychological resilience, and optimism (Buluç and Demir, 2015; Büyükgöze and Büyükgöze-Kavas, 2016; De Vries, Van den Hooff and De Ridder, 2006; Hechanova, Alampay and Franco, 2006; Ocak, Güler and Basım, 2016).

Although variously expressed by scientists, a common ground of the definition of job satisfaction is the gratification of employees with their jobs and workplaces. Koustelios (2001) defines it as employees' gratification for their job, and Muchinsky (2000) defines the gratification of the employees resulting from the harmony between the requirements of the job and the demands and needs of the employee. In many other definitions in the literature, it is seen that the common ground is employee's gratification for the job.

In the studies conducted about the job satisfaction variable, it is clearly seen that job satisfaction has a positive effect on the employees. Employees with high job satisfaction show healthier biological and mental aspects and fewer behavioral disorders (Feldman and Arnold, 1983). In another study, it was stated that job satisfaction positively affects the employees' personal trust, their harmony with the workplace, their cooperation and their solidarity and that it reduces their anxiety and stress (Şakac1, 2019). Employees develop a negative attitude towards the organization when they see that there is a big difference between the organization's opportunities and their own expectations. This attitude decreases the level of their job satisfaction as well (Eğinli, 2009). In the previous studies, it is stated that the job satisfaction levels of employees who are satisfied with their organizations and their jobs are generally high (Özgen and Yalçın, 2011) and that it contributes to the healthy functioning of the hierarchical structure in the organization (Demiray, 2018). Studies have determined that job satisfaction is affected by individual and organizational factors (Tengilimoğlu, 2005). Individual elements are defined as gender, age, seniority, marital status, education level, status, abilities, the personality of the employee and performance. And the organizational factors can be represented as the nature of the job, remuneration, rewarding and promotion system, working conditions, management style, job security, supervision, participation in decisions and relations with co-workers (Akbulut, 2015).

\section{Innovativeness}

Organizations compete with other organizations in which they are in the same league. It is quite important not to fall behind in this competition and to get ahead if possible. To do this, it is necessary to try new and 
advantageous methods that are different from classical practices. It would be insufficient to try to conduct innovative practices only with the management staff of the organizations. Employee's participation in the practices of innovativeness will increase the speed of organizational change, transformation and innovation. Employees can be innovative by finding their jobs meaningful, being pleased with them, being disposed to take responsibilities and trusting the organization (Parzefall, Seeck and Leppänen, 2008). Innovativeness is the creation, production or use of an idea, system, tool, program, policy, product or service differently from the previous practices (Güleş and Bülbül, 2002). In another definition, innovativeness is obtaining a new value or product by using a method or application that has not been used by another organization before (Ersoy and Muter, 2008).

Organizations should give importance to some issues for innovativeness to emerge. First of all, innovativeness is not a factor of change that only the managers should have. All employees must embrace innovativeness and strive for it. Employees should be provided with the opportunity to make decisions and take responsibility to contribute to innovativeness, and their innovative ideas should be valued (Pierce and Delbecq 1977). It is easier for employees who feel happy in the organization and have high job satisfaction to develop innovative practices. While operating an innovative process; problems should be recognized, innovation ideas and suggestions should be determined, infrastructure that will implement the new idea should be established (Scott and Bruce, 1994).

It is stated in different studies in the literature that innovative organizations are more competitive than the non-innovative ones and employees who are innovative are more successful than the non-innovative ones (Amabile, 1988; Unsworth and Parker, 2003; Van de Ven, 1986). Considering these characteristics of innovative employees, innovativeness in educational organizations should be researched with regards to its different aspects. Educational organizations primarily work to train qualified people for the countries and the whole world. Considering that the human resources of all other organizations are also trained by educational organizations, innovativeness in educational organizations should be primarily discussed. Thurlings, Evers, and Vermeulen (2015) stated that innovativeness has three aspects for educational organizations: Ensuring the harmony of individuals with society in the globalizing world and the age of information, producing new tools, methods, techniques and perspectives that are needed for educational sciences, ensuring that the educational organizations lead helping society to compete with other societies.

\section{Purpose and Hypotheses of The Research}

Above, the literature review of transformational leadership, job satisfaction and innovativeness has been made. The aim of this study, on the other hand, is to examine the relationship between transformational leadership in educational organizations with their employees' job satisfaction and innovativeness's. For this purpose, the following hypotheses have been developed. 


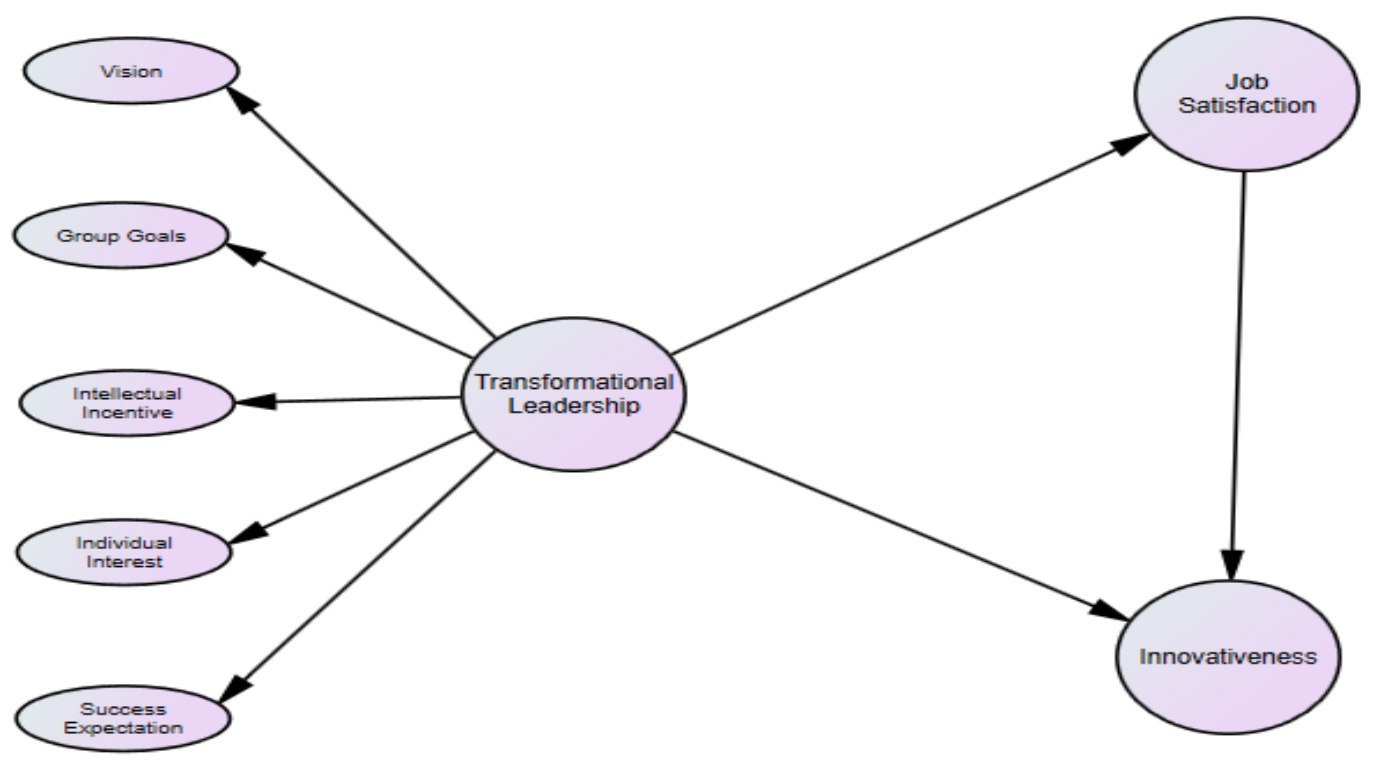

Figure 1. Predictive hypotheses for transformational leadership, job satisfaction and innovativeness

The following hypotheses have been tested in this research:

H1: Transformational leadership in elementary schools positively predicts teachers' job satisfaction.

H2: Transformational leadership positively predicts the innovativeness of elementary school teachers.

H3: The job satisfaction of elementary school teachers positively predicts their innovativeness.

H4: Transformational leadership in elementary schools has a mediating role in job satisfaction in predicting teachers' innovativeness.

\section{Method}

Since this research data is collected from teachers through a survey, ethics committee permission is required. For this reason, Inönü University Social and Humanities Scientific Research and Publication Ethics Committee has obtained the permission of the ethics committee with session 23 and Decision 1 on 30.11.2020.

\section{Research model}

In this research, the "Predictive Correlational Survey Model" was used. This model examines the relationships between variables that are included in the study (Cohen, Manion and Morrison, 2000; Karasar, 2012). In this study, the relationship of transformational leadership with the variables of innovativeness, job satisfaction, gender, seniority and age is examined.

\section{Population and Sample}

5715 teachers working in elementary schools affiliated to the Ministry of National Education in the province of Malatya in the academic year 2020-2021 constitute the target population of the study. Due to the difficulty in reaching the entire population, limited time and economic reasons, a sample large enough to represent the population was studied. While determining the sample of the research, the cluster sampling method, in which each school is accepted as a cluster, was used. The determination of the sample number was made with a formula prepared for situations where the total number of masses in the population is certain (Cochran, 1962; cited in Balc1, 2010). In the calculation, it was seen that the sufficient sample size could be 358 teachers. In this study, 498 teachers were evaluated as the sample. Values showing the demographic data (age, gender, seniority) of the sample are given in Table 1. 
Table 1. Frequency and percentage values of the demographic data of the sample.

\begin{tabular}{cccc}
\hline Variables & Value & $\mathbf{f}$ & \% \\
\hline \multirow{2}{*}{ Gender } & Male & 243 & 48,8 \\
& Female & 255 & 51,2 \\
\hline \multirow{2}{*}{ Age } & Age20-29 & 94 & 18,9 \\
& Age30-39 & 123 & 24,7 \\
& Age40-49 & 130 & 26,1 \\
& Age50-59 & 114 & 22,9 \\
& Age 60 and above & 37 & 7,4 \\
\hline \multirow{3}{*}{ Seniority } & $0-10$ years & 141 & 28,3 \\
& $11-20$ years & 194 & 39,0 \\
& $21-30$ years & 124 & 24,9 \\
& 30 years and above & 39 & 7,8 \\
\hline
\end{tabular}

\section{Data Collection and Analysis}

The teachers were informed about the research by going to the schools determined using the cluster sampling method and they were asked whether they would participate in the research voluntarily. The teachers who wanted to participate in the research were asked whether they wanted to fill out the scales as a paper printout or on the internet. The research data, in which everyone participated in the way they wanted, were analyzed on the computer with the SPSS program. During the analysis process, arithmetic means, T-test, correlation and regression analyzes were performed. The arithmetic mean of the answers to the scales:

"Low" if it is between 1.00-1.80,

"Generally Low" between 1.81-2.60

Between 2.61-3.40, it is "Intermediate"

"Generally High" between 3.41-4.20

If it is between 4.21-5.00, it will be evaluated as "High".

\section{Data Collection Tools}

\section{Transformational Leadership Scale}

The transformational leadership scale was developed by Podsakoff (1990) and was edited and adapted to Turkish by İşcan (2002). The scale is a five-point Likert scale and was answered between "Not convenient at all" (1) and "Fully convenient "(5). While analyzing the data, values with an arithmetic average of 1.00-1.80: were evaluated as "Transformational leadership level is very low", 1.81-2.60: were evaluated as "Transformational leadership level is low", 2.61-3.40: were evaluated as "I am uncertain about the sufficiency of transformational leadership", 3.41- 4.20: were evaluated as "Transformational leadership level is generally high", 4.21- 5.00: were evaluated as "Transformational leadership level is very high". The transformational leadership scale consisting of 23 items five-dimensional. The total variance explained in the scale with the data obtained has been $71 \%$. Within the scope of this research, validity and reliability analyzes for the scale were re-performed. Confirmatory Factor Analysis was conducted to check the construct validity of the scale. The values obtained are: $\chi 2 / \mathrm{df}=4.117(\mathrm{p}<.01), \mathrm{CFI}=.923, \mathrm{GFI}=.874, \mathrm{IFI}=.923$ and RMSEA $=.079$. According to these values, it can be said that the scale accords well. In the original scale, the Cronbach's alpha value, which is the internal consistency coefficient, is .93. The Cronbach's alpha internal consistency coefficient obtained in this study was determined as .90 .

\section{Job Satisfaction Scale}

The job satisfaction scale was developed by Hackman and Oldham (1975) and adapted to Turkish by Silah 
(2002). The scale was also made applicable to educational organizations by Taşdan (2008). The scale is a fivepoint Likert scale and was answered between "Not satisfactory at all" (1) and "Completely satisfactory" (5). While analyzing the data, values with an arithmetic average of 1.00-1.80: were evaluated as "Not satisfactory for me at all", 1.81- 2.60: were evaluated as "Not satisfactory enough for me ", 2.61-3.40: were evaluated as "Moderately satisfactory for me ", 3.41-4.20: were evaluated as "Very satisfactory for me ", 4.21- 5.00: were evaluated as "Completely satisfactory for me".The job satisfaction scale consisting of 14 items is onedimensional. The total variance explained in the scale with the data obtained was $64 \%$. Within the scope of this research, validity and reliability analyzes for the scale were re-performed. Confirmatory Factor Analysis was conducted to check the construct validity of the scale. The values obtained are: $\chi 2 / \mathrm{df}=3.909(\mathrm{p}<.01), \mathrm{CFI}$ $=.982, \mathrm{GFI}=.940, \mathrm{IFI}=.980$ and RMSEA $=.076$ and. According to these values, it can be said that the scale accords well. In the original scale, the Cronbach's alpha value, which is the internal consistency coefficient, is .95. The Cronbach's alpha internal consistency coefficient obtained in this study was determined as .89.

\section{Innovative Behavior Scale}

The innovativeness scale used in the study was developed by Scott and Bruce (1994) and adapted to Turkish by Çalışkan, Akkoç, and Turunç (2019). The scale consists of 6 items and one dimension. The scale, which is Likert-type, has five answering options: It was answered between "I never do this"(1) and "I always do it" (5). While analyzing the data, values with an arithmetic average of 1.00-1.80: were evaluated as "I never do this", 1.81- 2.60: were evaluated as "I usually do not do this", 2.61-3.40: were evaluated as "Sometimes I do it, sometimes I do not", 3.41-4.20: were evaluated as "I usually do this", 4.21- 5.00: were evaluated as "I always do this ".In this study, explanatory and confirmatory factor analyzes were made upon the scale. Since the Bartlett test result is significant and the Kaiser-Meyer-Olkin (KMO) coefficient is .83, the data matrix was found to be suitable for factor analysis. The only factor obtained in the scale explains $66.60 \%$ of the total variance in the measurement tool. Cronbach's alpha Reliability Coefficient of the innovativeness scale was found to be .90. The Cronbach' alpha internal consistency coefficient obtained in this study was determined as .88 . Confirmatory factor analysis was conducted to check the construct validity of the scale. The obtained values are: $\chi 2 / \mathrm{df}=3.786(\mathrm{p}<.01), \mathrm{CFI}=.994, \mathrm{GFI}=.990, \mathrm{IFI}=.994$ and $\mathrm{RMSEA}=.074$.

The skewness and kurtosis coefficients and normality values of the data were examined and it was observed that these values were between " -1 " and " +1 ". When research data are collected from a single source or when several scales are used simultaneously, "common method variance deviation" may occur. In this study, Harman's single factor test (Podsakoff et al. 2003) was applied to understand whether there is such a problem in the scales. Acyclic factor analysis was performed with a total of 43 items in the three scales used in the study. The variance explained by the single factor that emerged was found to be $27 \%$. This low variance shows that there is no common variance problem in the scales.

\section{Results}

Findings showing the levels of transformational leadership, job satisfaction and innovativeness in elementary schools according to teachers' views are given in Table 2.

Table 2. Levels of transformational leadership, job satisfaction and innovativeness level in elementary schools

\begin{tabular}{lccc}
\hline & N & X & sd \\
\hline Transformational leadership & 498 & 4.057 &, 467 \\
Job satisfaction & 498 & 3,973 &, 455 \\
Innovativeness & 498 & 4,073 &, 743 \\
\hline
\end{tabular}

Data in the Table 2 shows that according to the perceptions of elementary school teachers, the transformational leadership average in elementary schools is 4.057. This shows that the average transformational leadership has a "generally high" level in elementary schools. The average job satisfaction is 3.973. According to this finding, the teachers evaluated their job satisfaction as "Very satisfactory for me ". This level means that teachers' job satisfaction is generally high in elementary schools. Looking at the innovativeness average, we see an average of 4.073. According to this finding, teachers expressed their 
innovativeness as "generally high".

In the research; whether the levels of job satisfaction and innovativeness differ significantly in elementary schools with regards to gender, age and seniority were examined. As a result of this analysis, it was seen that the gender variable doesn't differ significantly in terms of transformational leadership, innovativeness and job satisfaction. It is not included in the table below as it does not show a significant change. Transformational leadership, innovativeness and job satisfaction were analyzed in terms of age variables and are shown in Table 3.

Table 3. Table of $X$ and $P$ values by age variable of transformational leadership, job satisfaction and innovativeness

\begin{tabular}{|c|c|c|c|c|c|c|c|}
\hline \multirow{6}{*}{$\begin{array}{l}\text { Transformational } \\
\text { Leadership }\end{array}$} & Age & $\bar{x}$ & $\begin{array}{c}20-29 \\
\text { p value } \\
\end{array}$ & $\begin{array}{c}30-39 \\
\text { p value } \\
\end{array}$ & $\begin{array}{c}40-49 \\
\text { p value }\end{array}$ & $\begin{array}{c}50-59 \\
\text { p value } \\
\end{array}$ & $\begin{array}{c}60 \text { and above } \\
p \text { value }\end{array}$ \\
\hline & $20-29$ & 3,9681 & & & & & \\
\hline & $30-39$ & 4,0032 & ,988 & & & & \\
\hline & $40-49$ & 4,3264 &, $000^{a}$ &, $000^{c}$ & & & \\
\hline & $50-59$ & 4,2323 &, $001^{\mathrm{b}}$ &, $004^{\mathrm{d}}$ & 607 & & \\
\hline & 60 and above & 4,1316 & ,467 & 669 & 241 &, 839 & \\
\hline \multirow{5}{*}{ Job Satisfaction } & $20-29$ & 3,9293 & & & & & \\
\hline & $30-39$ & 3,9315 & 1,000 & & & & \\
\hline & $40-49$ & 3,9841 & ,918 & ,908 & & & \\
\hline & $50-59$ & 4,1328 &, $016^{\mathrm{e}}$ & ,008g & 103 & & \\
\hline & 60 and above & 4,2336 &, $007^{\mathrm{f}}$ &, $005^{\mathrm{h}}$ &, $036^{\mathrm{i}}$ & ,802 & \\
\hline \multirow{5}{*}{ Innovativeness } & $20-29$ & 4,3333 & & & & & \\
\hline & $30-39$ & 4,0556 &, $043^{\mathrm{k}}$ & & & & \\
\hline & $40-49$ & 3,9885 &, $004^{1}$ & ,953 & & & \\
\hline & $50-59$ & 3,8436 &, $000^{\mathrm{m}}$ & 172 &, 545 & & \\
\hline & 60 and above & 3,2973 &, $000^{\mathrm{n}}$ & ,000p &, $000^{r}$ &, $001^{\mathrm{s}}$ & \\
\hline
\end{tabular}

If we examine the transformational leadership in Table 3, it is seen that the $p$ values of the $40-49$ age group and the 50-59 age group differ significantly compared to the other age groups $(p=.000 a, p=.001 b, p=.000 c$, $\mathrm{p}=.004 \mathrm{~d})$. When the averages are examined to understand the direction of this differentiation, it is seen that the averages of the 40-49 age group $(\bar{x}=4.3264)$ and the 50-59 age group $(\bar{x}=4.2323)$ are significantly higher than the age groups of 20-29, 30-39 and 60 years and above. Evaluation of these findings: Teachers in the age groups of 40-49 and 50-59 stated that transformational leadership was at higher levels in elementary schools.

When job satisfaction in primary schools is examined by age variable, it is observed that teachers aged 50 and above differ significantly from younger teachers $(\mathrm{p}=.016 \mathrm{e}, \mathrm{p}=.007 \mathrm{f}, \mathrm{p}=.008 \mathrm{~g}, \mathrm{p}=.005 \mathrm{~h}, \mathrm{p}=.036 \mathrm{i})$. The average of the job satisfaction points of teachers aged 50 and above is significantly higher than that of young teachers $(\bar{x}=4.1328, \bar{x}=4.2336)$. When the innovativeness of elementary school teachers is examined according to the age variable, it is seen that the teachers in the 20-29 age group differ significantly with other age groups $(\mathrm{p}=.043 \mathrm{k}, \mathrm{p}=.004 \mathrm{l}, \mathrm{p}=.000 \mathrm{~m}, \mathrm{p}=.000 \mathrm{n})$. It is seen that the innovativeness of teachers aged 60 and above is significantly lower than the innovativeness levels of all teachers $(\bar{x}=3.2973)$. Transformational leadership, job satisfaction and innovativeness were examined according to the seniority of teachers and are shown in Table 4 .

Table 4. Table of $X$ and $P$ values by seniority variable of transformational leadership, job satisfaction and innovativeness

\begin{tabular}{|c|c|c|c|c|c|c|}
\hline \multirow{5}{*}{$\begin{array}{l}\text { Transformational } \\
\text { Leadership }\end{array}$} & Seniority & $\bar{x}$ & $\begin{array}{c}0-10 \\
\text { years }\end{array}$ & $11-20$ years & $21-30$ years & 30 years above \\
\hline & $0-10$ years & 3,9593 & & & & \\
\hline & $11-20$ years & 4,0964 & ,051 & & & \\
\hline & 21-30 years & $4,2423^{e}$ &, $000^{a}$ &, $043^{c}$ & & \\
\hline & 30 years above & $4,3244^{\mathrm{f}}$ &, $000^{\mathrm{b}}$ &, $036^{\mathrm{d}}$ & ,796 & \\
\hline
\end{tabular}

Job Satisfaction

$0-10$ years

3,9463 
Transformational leadership job satisfaction's relationship with...

\begin{tabular}{|c|c|c|c|c|c|}
\hline & $11-20$ years & 4,0096 & 611 & & \\
\hline & 21-30 years & 4,0461 & ,302 & ,905 & \\
\hline & 30 years above & 4,1703 & ,037 & ,199 & ,467 \\
\hline \multirow{4}{*}{ Innovativeness } & $0-10$ years & 4,2695 & & & \\
\hline & $11-20$ years & 3,8746 &, $000 \mathrm{~g}$ & & \\
\hline & 21-30 years & 3,8817 &, $000^{\mathrm{h}}$ & 1,000 & \\
\hline & 30 years above & 3,8419 &, $006^{\mathrm{i}}$ & ,994 & 991 \\
\hline
\end{tabular}

In Table 4, transformational leadership, job satisfaction and innovativeness were analyzed according to the seniority of teachers. It is seen that the transformational leadership perceptions of teachers with more than 20 years of seniority differ significantly from teachers with less seniority $(p=.000 a, p=.000 b, p=.043 c, p=$ $.036 \mathrm{~d}$ ). Teachers with more than 20 years of seniority stated that transformational leadership are at a higher level in their schools $(\bar{x}=4,2423 \mathrm{e}, \bar{x}=4,3244 \mathrm{f})$.

When the job satisfaction is examined, it is seen that the teachers who are in the seniority group of 30 years and above significantly differ from teachers with a seniority of $0-10$ years $(p=.037)$. When the averages of these two groups are examined, it is seen that the teachers in the 30 years and above group $(\bar{x}=4.1703)$ have higher-level job satisfaction. When we look at the innovation, we see that teachers with a seniority of $0-10$ years differ significantly from other teachers $(\mathrm{p}=.000 \mathrm{~g}, \mathrm{p}=.000 \mathrm{~h}, \mathrm{p}=.006 \mathrm{i})$. When the average of innovativeness in seniority groups is examined, it is seen that teachers with 0-10 years of seniority have higher points $(\bar{x}=4.2695)$.

To determine whether transformational leadership in elementary schools has a significant relationship with job satisfaction and innovativeness, a correlation analysis was conducted and the findings are given in Table 5.

Table 5. Correlation values between teachers' job satisfaction levels and their innovativeness levels

\begin{tabular}{ccccc}
\hline & & $\begin{array}{c}\text { Transformational } \\
\text { Leadership }\end{array}$ & Job Satisfaction & Innovativeness \\
\hline \multirow{2}{*}{ Transformational Leadership } & $\mathrm{r}$ & 1 &, 633 &, 566 \\
& $\mathrm{p}$ & $\mathrm{r}$ &, $000^{*}$ &, $000^{*}$ \\
\hline \multirow{2}{*}{ Job Satisfaction } & $\mathrm{r}$ &, 633 & 1 &, $000^{*}$ \\
& $\mathrm{p}$ &, $000^{*}$ &, 647 & 1 \\
\hline \multirow{2}{*}{ Innovativeness } & $\mathrm{r}$ &, 566 &, $000^{*}$ & \\
\hline
\end{tabular}

${ }^{* *} \mathrm{p}=, 000$

In correlation analysis, if the $\mathrm{r}$ value is between 00- .29, it shows a low level of relationship, if it is between 30-, 69, it shows a medium level of relationship and if it is between 70-1.00, it shows a high level of relationship (Saruhan and Özdemirci, 2013). According to Table 5, it is revealed that there is a positive, medium level and significant relationship between transformational leadership and job satisfaction in elementary schools $(r=, 633 ; p=000)$. Similarly, there is a positive, medium level and significant relationship between transformational leadership and innovativeness $(\mathrm{r}=, 566 ; \mathrm{p}=, 000)$. And if we look at the relationship between job satisfaction and innovativeness, it is seen that there is a medium level and significant relationship $(\mathrm{r}=, 647 ; \mathrm{p}=, 000)$. After determining this significant relationship, structural equation modelling was performed to determine the predictive status of transformational leadership concerning job satisfaction and innovativeness. 


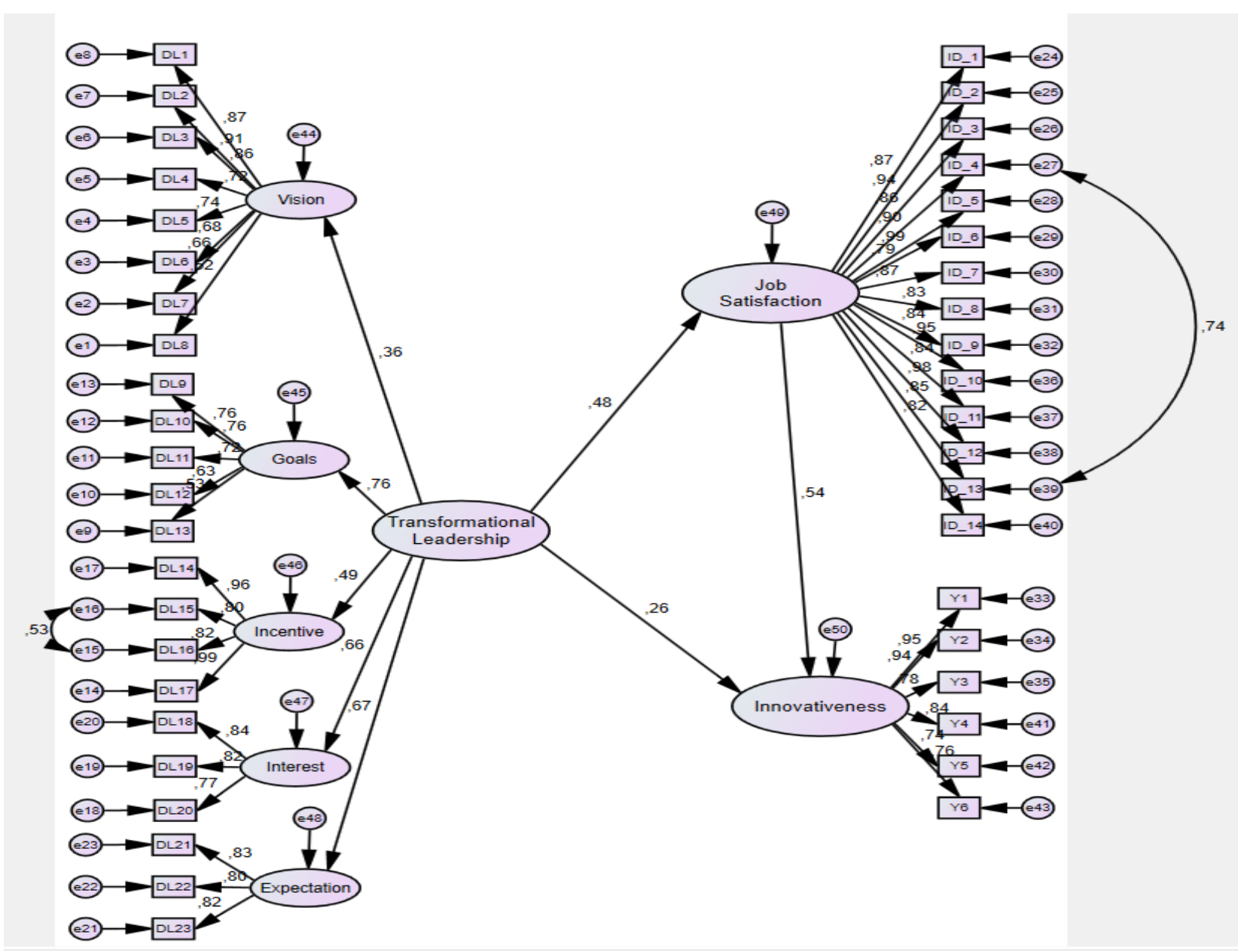

Figure 2. Predictive model of transformational leadership with respect to job satisfaction and innovativeness

The model obtained as a result of standardized regression coefficients ( $\beta$ ), standard errors (SE), the critical values (CR) and $P$ values are given in Table 6.

Table 6. The result of regression analysis.

\begin{tabular}{lcccc}
\hline & $\boldsymbol{\beta}$ & SE & CR & p \\
\hline Transformational leadership - Job satisfaction & .484 & .188 & 4.567 & $<0.001$ \\
\hline Transformational leadership -Innovativeness & .260 & .190 & 4.643 & $<0.001$ \\
\hline Job satisfaction -Innovativeness & .539 & 184 & 4.379 & $<0.001$ \\
\hline
\end{tabular}

According to the structural model in Figure 2, which produces the best-fit indices, transformational leadership positively predicts teachers' job satisfaction $(=.484, \mathrm{p}<0.01)$ and innovativeness $(=.260, \mathrm{p}<0.01)$. This situation shows that as the positive perception of transformational leadership increases, the innovativeness of teachers will also increase. When the $\beta$ values are examined, it is seen that a one-unit increase in transformational leadership will provide a 48-unit increase in teachers' job satisfaction and a .26-unit increase in their innovativeness.

According to the data obtained in Figure 2, teachers' job satisfaction significantly predicts their innovativeness $(=.539, \mathrm{p}<0.01)$ as well. These data show that as the levels of job satisfaction of teachers increases, their innovativeness will also increase. When the $\beta$ value of this prediction is examined, it shows that a one-unit increase in teachers' job satisfaction will provide an increase of .54 units in innovativeness.

There are direct effects as well as indirect effects between latent variables in the structural model. In the model, it was determined that teachers' transformational leadership perceptions positively affect their innovativeness $(\beta=.26)$ through job satisfaction. The indirect impact level of transformational leadership on innovativeness was calculated by multiplying the path coefficient between transformational leadership and 
job satisfaction and the path coefficient between job satisfaction and innovation. Fit indices for transformational leadership - job satisfaction - innovativeness model: $\chi 2=1608.57, \mathrm{df}=549, \chi 2 / \mathrm{df}=2.93, \mathrm{p}=$ $.000, \mathrm{NFI}=.91, \mathrm{IFI}=.95, \mathrm{TLI}=.94, \mathrm{CFI}=.95, \mathrm{RMSEA}=.07$

\section{Conclusion and Discussion}

This study, which was carried out in educational organizations was conducted to better understand the impact of transformational leadership on employees' job satisfaction and innovativeness. In the study, first of all, it was found that as transformational leadership increases, teachers' job satisfaction increases as well. This situation shows that the H1 hypothesis has been confirmed. The second data obtained is that as the transformational leadership increases in the school, the innovativeness of teachers' increases as well. This situation shows that the $\mathrm{H} 2$ hypothesis has also been confirmed. Another result is that teachers' job satisfaction affects their innovativeness positively. And this result confirms the $\mathrm{H} 3$ hypothesis. Indirect effects were also found among latent variables in the structural model of the study. Transformational leadership indirectly affects the innovativeness of teachers through job satisfaction positively. And this result confirms the H4 hypothesis.

There are many studies in the literature indicating that leadership positively affects innovativeness and job satisfaction (Aykanat and Çalışkan, 2019; Bozkurt and Göral, 2013; Černe, Jaklic and Škerlavaj, 2013; Contreras, 2017; Eğriboyun, 2015; Fidan, 2019; Gümüşlüoğlu and İlsev, 2009; Kırkpınar and İşcan, 2018; Nödl, 2017; Önhon, 2016). This study specifically examines the relationship between transformational leadership, job satisfaction, and innovativeness. It is seen that transformational leadership, job satisfaction and innovation levels in elementary schools are generally at "high" levels. In many studies in the literature, it is seen that transformational leadership (Aksel and Elma, 2018; Eryılmaz, 2006; Göksel, 2017; Kiriş, 2013), job satisfaction (Çoruk and Çiçek, 2017; Özkan, 2017) and innovation (Özbek, 2014; Saraç, 2019) levels are at high levels.

When the relationship between age variable and transformational leadership is examined, it is observed that teachers between the ages of 40-59 have a higher level of transformational leadership perception compared to younger teachers and teachers aged 60 and above. It may be normal for teachers above the age of 60 to lose their belief in a transformation in the organization, as there is little time left for them till retirement. Young teachers, on the other hand, may have had a lower level of transformational leadership perception, as they could have found the transformation characteristics of administrators to be slow and ineffective. When the results obtained in this study are compared with the researches in the field, similar results are seen. In the study of Lan, Chang, Ma, Zhang and Chuang (2019), it is seen that the transformational leadership perceptions of young and old teachers are lower than those of teachers in the middle age group. In the study conducted by Şirin, Aydın, and Bilir (2018), young participants and older participants had a lower average than middleaged participants, but this difference was not significant.

When the relationship of age variable with job satisfaction and innovativeness is examined, it is observed that the job satisfaction of teachers over the age of 50 is higher than that of young teachers and that teachers under the age of 30 have higher innovativeness levels than the levels of other teachers. When the previous researches are examined, it is seen that the age variable makes a significant difference in job satisfaction and that older employees have higher job satisfaction than young employees in general (Bostancioğlu, 2008; Demirtaş and Alanoğlu, 2015; Şeker and Zırhlığlu, 2009; Yeğin, 2009; Yelboğa, 2007). Different results have been found in previous studies on whether the innovativeness of employees varies significantly depending on the age factor. In the study conducted by Guillen and Kunze (2019), it was stated that innovativeness levels are high until the age of 35 and they decrease at later ages. And in this study, these levels are at highest between the ages of 20-30 and they decrease every year. These two studies are considerably similar. In a study conducted by Kosa (2019) on managers, the innovativeness levels of managers under the age of 30 were significantly higher than other managers.

In this study, it was observed that the transformational leadership perceptions of teachers with more than 20 years of seniority are significantly higher than young teachers. According to many studies in the literature, 
employees with low seniority have significantly lower transformational leadership points (Doğan, 2010; Yılmaz and Yüksel Şahin, 2016). In some studies, it was found that the seniority variable did not make a significant difference for transformational leadership (Bilgin, 2018; Kaygın and Yerdelen-Kaygın, 2012; Şirin, 2008). In the research conducted by Avc1 (2015), it is stated that teachers with high seniority generally have high transformational leadership points, and teachers with first 1-year seniority have high transformational leadership points as well.

In this study, it is seen that the job satisfaction of employees with more than 30 years of seniority is significantly higher than those with less seniority. If to look at the studies in the literature, studies are designating that as the seniority increases, job satisfaction also increases (Çağlar and Demirtaş, 2011; Şeker and Zırhlığlu, 2009), and there are studies also designating that as the seniority increases, job satisfaction decreases (Darmody and Smyth, 2011; Karataş and Güleş, 2010). And in some studies, was found that seniority does not significantly affect job satisfaction (Karadağ, Başaran, and Korkmaz 2009; Şanlı and Akbaş, 2009; Şeren and Özcan, 2019; Taşdan and Tiryaki, 2008).

In this study, it was found that teachers with a seniority of 0-10 years have significantly higher levels of innovativeness than those of other teachers. There are also studies in the literature showing that as seniority increases, conservatism and inflexibility against change in employees increases and innovativeness decreases (Çelik, 2006; Yapıcı and Kaya, 2020). However, there are no studies in the literature showing that the variable of seniority does not significantly affect the levels of innovativeness of employees (Argon, İsmetoğlu and Çelik Yılmaz, 2015; Saraç, 2019).

As a result of the correlation analysis conducted to determine whether transformational leadership in elementary schools has a significant relationship with job satisfaction and innovativeness, it was seen that all three variables were moderately related to each other. After determining this relationship, structural equation modelling was performed to determine the direction and level of this relationship. The obtained results show that transformational leadership positively and directly predicts job satisfaction and innovativeness. At the same time, another obtained result shows that transformational leadership indirectly predicts innovativeness through job satisfaction positively.

When previous studies in the literature are examined, it is seen that transformational leadership has a positive relationship with job satisfaction (Bryman, 1992; Eğriboyun, 2015; Gurbetoğlu and Genç Yüksel, 2019; Ledoux, 1999). In the study by Mert, Dördüncü and İncaz (2019), it is stated that transformational leadership positively predicts the job satisfaction of employees, as it is stated in this study. Another study in which it is stated that transformational leadership positively predicts the job satisfaction of employees was conducted by Berson and Linton (2005). There are many studies in the literature showing that transformational leadership positively predicts the job satisfaction of employees (Bogler, 2001; Eren and Titizoğlu, 2014; Smoak, 2008; Sung, 2007).

Another result obtained in this study is that transformational leadership has a positive relationship with innovativeness and transformational leadership significantly predicts innovativeness. In the study conducted by Korku (2008), a positive relationship between transformational leadership and innovativeness was determined. In addition, it was concluded that transformational leadership significantly predicts the innovative climate. Many studies in the literature determine the relationship between transformational leadership and innovativeness (Aarons and Sommerfeld, 2012; Jaiswal and Dhar, 2015; Önhon, 2016; Sarros, Cooper and Santora, 2008). A result showing that innovativeness is predicted by transformational leadership is seen in the study conducted by Gümüşlüoğlu and İlsev (2009). In addition, in the studies of Şentürk, Durak, Yılmaz, Kaban, Kök and Baş (2016), Vaccaro, Jansen, Van Den Bosch and Volberda (2012) and Jung, Chow and $\mathrm{Wu}$ (2003), it is stated that transformational leadership positively predicts the innovativeness levels of employees.

Another result of the research is that job satisfaction predicts innovativeness. Many factors affecting job satisfaction have been examined in the field, but not much emphasis has been placed on what affects job satisfaction. In this study, the relationship between job satisfaction and innovativeness was also examined. In 
the correlation analysis, it was found that there is a moderate relationship between these two variables. Through the regression analysis that was conducted to determine the direction of this relationship, it was concluded that job satisfaction predicts innovativeness. When similar studies are examined in the literature, it is seen that in the studies conducted by İspir (2018) and Akyıldız (2014), a positive relationship between innovativeness and job satisfaction is designated. Again, in another study conducted by Altan and Özpehlivan (2019), it is seen that job satisfaction has a significant and positive effect on innovativeness. According to the result of that study, it is stated that as job satisfaction increases, innovativeness increases as well. In the study of Tang, Shao and Chen (2019), job satisfaction positively predicts innovativeness levels of the employees. Although the direct predictive level of job satisfaction on levels of innovativeness of the employees is low, it is seen that job satisfaction significantly predicts innovativeness through the mediating effect of organizational commitment. The findings obtained in the studies mentioned above and in this study are largely similar. However, it should be stated that there are very few studies in the literature of educational sciences investigating the effects of job satisfaction on innovativeness.

The results of current research and previous research in the field are largely similar. This indicates the reliability of the results of the research. However, since there are no studies in which these three variables are considered together and in educational organizations, it can be decried as an original study in the field.

\section{Limitations and Suggestion}

This research is limited to Malatya province, 2020-2021 academic year and elementary school teachers. Given these limitations, new researches can be tested at other levels of education, in different cities or countries, and at different times. In addition, another limitation of the study is that it was conducted during the COVID 19 process. The difficulties in reaching the participants, the transmission and collection of most of the forms through digital channels are the important limitations of the research.

As a result of this study, it is seen that, in general, the transformational leadership and job satisfaction levels of teachers with young age and low seniority are low and their level of innovativeness is high. These results can be discussed with different studies. In this study, it was seen that transformational leadership predicts job satisfaction and innovativeness. Based on this result, it can be recommended for educational organizations to adopt transformational leadership to increase the levels of job satisfaction and innovativeness of their employees. Considering that job satisfaction predicts innovativeness, which is another result of this study; organizations may try to increase teachers' levels of job satisfaction to increase their levels of innovativeness. Teachers' expectations and complaints that are affecting their job satisfaction can be examined through qualitative studies. The subject of this research can be studied with Online Photovoice (OPV), which is a different research method.

\section{Declarations}

\section{Acknowledgements: Not applicable}

Ethics committee approval: Since this research data is collected from teachers through a survey, ethics committee permission is required. For this reason, İnönü University Social and Humanities Scientific Research and Publication Ethics Committee has obtained the permission of the ethics committee with session 23 and Decision 1 on 30.11.2020.

Funding: Funding for the research was provided by the author.

\section{References}

Aarons, G. A. \& Sommerfeld, D. H. (2012). Leadership, innovation climate, and attitudes toward evidencebased practice during a statewide implementation. Journal of the American Academy of Child \& Adolescent Psychiatry, 51(4), 423-431.

Akbolat, M., Işık, O. \& Yılmaz, A. (2013). Dönüşümcü liderlik davranışının motivasyon ve duygusal bağlılığa etkisi. Uluslararası İktisadi ve İdari İncelemeler Dergisi, 6(11), 35- 50. 
Akbulut, B. (2015). Ortaöğretim kurumlarında görev yapan öğretmenlerin örgütsel imaj algıları ile iş doyumu düzeyleri arasındaki ilişki (Unpublished doctorate thesis). Hacettepe University, Ankara

Aksel, N. \& Elma, C. (2018). Ortaokul müdürlerinin dönüşümcü liderlik davranışları ile öğretmenlerin motivasyonu arasındaki ilişki. Abant İzzet Baysal Üniversitesi Ĕ̆itim Fakültesi Dergisi, 18(3), 1252-1268.

Akyıldız, S. (2014). Örgüt kültürünün çalişanlarda inovatif düşünce geliştirme, iş tatmini ve örgüt bağliliğina etkisi: bilişim sektöründe bir uygulama (Unpublished master thesis). İstanbul Gelişim University, İstanbul.

Altan S. \& Özpehlivan M. (2019). Bilişim sektöründe entelektüel sermaye, iş tatmini ve inovasyon yönlülük arasındaki ilişkinin incelenmesi: İstanbul ilinde bir uygulama. Gümüşhane Üniversitesi Sosyal Bilimler Enstitüsü Elektronik Dergisi, 10(1), 154-167.

Altın, F. (2019). Okul müdürlerinin dönüşümcü liderlik ve örgütsel yenileşme özelliklerinin öğretmen görüşleri açısından incelenmesi (Unpublished master thesis). Balıkesir University, Balıkesir.

Amabile, T. M. (1988). A model of creativity and innovation in organizations. Research in Organizational Behavior, 10, 123-167.

Arago'n-Correa, J.A., Garcı'a-Morales, V. J. \& Cordo'n-Pozo, E. (2007). Leadership and organizational learning's role on innovation and performance: lessons from Spain. Industrial Marketing Management, 36(3), 349-359.

Argon, T., İsmetoğlu, M. \& Çelik Yılmaz, D. (2015). Branş öğretmenlerinin teknopedagojik eğitim yeterlilikleri ile bireysel yenilikçilik düzeylerine ilişkin görüşleri. Journal of Research in Education and Teaching, 4(2), 319-333.

Avcı, A. (2015). Öğretmen algılarına göre okul müdürlerinin liderlik stilleri. Hasan Ali Yücel Eğitim Fakültesi Dergisi, 12-2(24), 161-189.

Aykanat, Z. \& Çalışkan, M. (2019). Dönüştürücü liderlik ve örgütsel yenilikçilik arasındaki ilişki: Bir kamu kurumu örneği. Kafkas Üniversitesi İktisadi ve İdari Bilimler Fakültesi Dergisi, 10(20), 829-857.

Balc1, A. (2010). Sosyal bilimlerde araştırma: Yöntem, teknik ve ilkeler. Ankara: Pegem A Yayıncılık.

Bass, B. M. (1998). Transformational leadership: Industrial, military, and educational impact. Mahwah, N.J.: Lawrence Erlbaum Associates Publishers

Berson, Y. \& Linton, J. D. (2005). An examination of the relationships between leadership style, quality, and employee satisfaction in R\&D versus administrative environments. RED Management, 35(1), 51-60.

Bilgin, H. (2018). Özel eğitim öğretmenlerinin algilarina göre okul müdürlerinin liderlik özelliklerinin incelenmesi İstanbul Esenyurt örneği (Unpublished master thesis). Marmara University and Sabahattin Zaim University, İstanbul.

Bogler, R. (2001). The influence of leadership style on teacher job satisfaction. Educational Administration Quarterly, 37(5), 662-683.

Bostancioğlu, S. (2008). The effect of working values on the relationship between job satisfaction and turnover intenition (Unpublished master thesis). Marmara University, İstanbul

Bozkurt, O. \& Göral, M. (2013). Modern liderlik tarzlarının yenilik stratejilerine etkisini belirlemeye yönelik bir çalışma. Anadolu Universitesi Sosyal Bilimler Dergisi, 13(4), 1-14.

Bronfenbrenner, U. (1979). The ecology of human development. Cambridge, MA: Harvard University Press.

Bryman, A. (1992). Charisma and leadership in organizations. London: Sage.

Buluç, B., \& Demir, S. (2015). İlk ve ortaokul öğretmenlerinin özyeterlik algıları ile iş doyumları arasındaki ilişki. Ahi Evran Üniversitesi Kırşehir Ĕ̆itim Fakültesi Dergisi, 16(1), 289-308.

Burns, M. G. (1978). Leadership. Newyork: Harper-Row. 
Büyükgöze, H., \& Büyükgöze-Kavas, A. (2016). Psikolojik sermaye ile iş doyumu ilişkisinin öğretmen görüşlerine göre incelenmesi. In K. Ersanlı (Ed.). Hedefe Doğru İnsan, 2, 176-185.

Çağlar, Ç. \& Demirtaş, H. (2011). Dershane öğretmenlerinde tükenmişlik ve iş doyumu. E-International Journal of Educational Research, 2(2), 30-49.

Çalışkan, A., Akkoç, I. \& Turunç, O. (2019). Yenilikçi davranış: Bir ölçek uyarlama çalışması. Uluslararası Íktisadi ve İdari Bilimler Dergisi, 5(1), 94-111.

Černe, M., Jaklic, M., \& Škerlavaj, M. (2013). Authentic leadership, creativity and innovation: A multilevel perspective. Leadership, 9(1) 63-85.

Coad, A.F. \& Berry, A.J. (1998). Transformational leadership and learning orientation. Leadership $\mathcal{E}$ Organization Development Journal, 19(3), 164-172.

Cohen, L., Manion, L., \& Morrison, K. (2000). Research methods in education (5th ed). London: Routledge Falmer.

Contreras, F. (2017). Leadership and employees' innovative work behavior: Test of a mediation and moderation model. Asian Social Science, 13(9), 9-25.

Çoruk, A. \& Çiçek, H. K. (2017). İlköğretim okullarında görev yapan öğretmenlerin okul yaşam kalitesi algıları ile iş doyumu algıları arasındaki ilişki. Dicle Üniversitesi Ziya Gökalp Ĕ̆itim Fakültesi Dergisi, (31), 750761.

Darmody, M. \& Smyth, E. (2011). Job satisfaction and occupational stress among primary school teachers and school principals in Ireland. Dublin: ESRI Publishing, the Teaching Council

De Vries, R. E., Van den Hooff, B. J., \& De Ridder, J. A. (2006). Explaining knowledge sharing: The role of team communication styles, job satisfaction, and performance beliefs. Communication Research, 33(2), 115 - 135.

Demiray, S. (2018). Psikolojik güçlendirme ile iş doyumu arasındaki ilişki (Unpublished master thesis). Pamukkale University, Denizli.

Demirtaş, Z. \& Alanoğlu, M. (2015). Öğretmenlerin karara katılımı ve iş doyumu arasındaki ilişki. Ahi Evran Üniversitesi Kırşehir Eğitim Fakültesi Dergisi, 16(2), 83-100.

Doğan, S. (2010). Leadership behaviors of the primary school administrators according to the opinions of teachers andadministrators. Inonu University Journal of the Faculty of Education, 11(3), 101-123.

Dublin, A.J. (2001). Leadership research finding, practice and skills. Newyork: Haugton Mifflin Company.

Eğinli, A. T. (2009). Çalışanlarda iş doyumu: Kamu ve özel sektör çalışanlarının iş doyumuna yönelik bir araştırma. Atatürk Üniversitesi İktisadi ve İdari Bilimler Fakültesi Dergisi, 23(3), 35-52.

Eğriboyun, D. (2015). Ortaöğretim okullarında görev yapan yönetici ve öğretmenlerin liderlik uygulamaları ve iş doyumu algıları arasındaki ilişki. Gaziantep Üniversitesi Sosyal Bilimler Dergisi, 14(1), 241-275.

Eren, M.Ş. \& Titizoğlu, Ö.Ç. (2014). Dönüşümcü ve etkileşmci liderlik tarzlarının örgütsel özdeşleşme ve iş tatmini üzerindeki etkileri. Sosyal ve Ekonomik Araştırmalar Dergisi, 14(27), 275-303.

Ersoy A.B. \& Muter Ş.C. (2008). Yenilikçiliğe yönelik devlet uygulamaları ve AB karşılaştırması [Government practices for innovation and EU comparison]. Yönetim ve Ekonomi, 15(1), 59-74.

Eryılmaz, F. (2006). Endüstri meslek lisesi okul müdürlerinin dönüşümcü liderlik özelliklerine sahip olma düzeyleri (Unpublished master thesis), Gazi University, Ankara.

Feldman, C.D. \& Arnold, J.H. (1983). Managing individual and group behavior in organization. Auckland: Mc.Graw-Hill International Book Company

Fidan, M. (2019). Öğretmenlerde bireysel inovasyon ile öz liderlik arasındaki. Uluslararası Yonetim Akademisi Dergisi, 2(3), 518-527. 
Glad, B. \& Blanton, R.M. (1997). F.W. De Klerk and Nelson Mandela: A study in cooperative transformational leadership. Presidential Studies Quarterly, 27(3), 565-590.

Göksel, G. Y. (2017). Okul yöneticilerinin dönüşümcü liderlik özelliklerini gösterme düzeylerine ilişkin öğretmen görüşleri (Unpublished master project). Pamukkale University, Denizli.

Göksoy, S., Torlak, E. \& Uğuz, B. (2019), Okul müdürlerinin dönüşümcü liderlik roller [Transformational leadership roles of school principals]. Düzce Üniversitesi Sosyal Bilimler Enstitüsü Dergisi, 9(2), 29-222.

Guillen, L. \& Kunze, F. (2019). When age does not harm innovative behavior and perceptions of competence: Testing interdepartmental collaboration as a social buffer. Human Resource Management, 58(3), 301-316.

Güleş, H.K. \& Bülbül H. (2002). Yenilikçilik: İşletmeler için stratejik rekabet aracı. Ankara: Nobel Yayın Dağıtım.

Gümüşlüoğlu, L. \& İlsev, A. (2009). Transformational leadership, creativity, and organizational innovation. Journal of Business Research, 6 (4), 461-473.

Güney S. (2017). Örgütsel Davranış. Ankara: Nobel Yayıncılık.

Gurbetoğlu, A. \& Genç Yücel B. (2019). Okulöncesi eğitim kurumu yöneticilerinin liderlik stilleri ile öğretmenlerin iş doyumu arasındaki ilişkinin incelenmesi.Temel Eğitim Dergisi, 1(2), 6-19.

Hackman, J. R., \& Oldham, G. R. (1975). Development of the job diagnostic survey. Journal of Applied psychology, 60(2), 159-170.

Hechanova, R. M., Alampay, R. B. A., \& Franco, E. P. (2006). Psychological empowerment, job satisfaction and performance among Filipino service workers. Asian Journal of Social Psychology, 9(1), 72-78.

İşcan, Ö. F. (2002). Küresel işletmecilikte dönüştürücü liderlik anlayışı -büyük ölçekli işletmelerde bir uygulama (Unpublished doctorate thesis). Atatürk University, Erzurum.

İspir, İ. (2018). Çalışanların iş tatmini ile yenilikçi davranışının bireysel performansa etkisi. İnönü Üniversitesi Uluslararası Sosyal Bilimler Dergisi, 7(2), 120-135.

Jaiswal, N. K. \& Dhar, R. L. (2015). Transformational leadership, innovation climate, creative self-efficacy and employee creativity: A multilevel study. International Journal of Hospitality Management, 51, 30-41.

Jung, D. I., Chow, C. W. \& Wu, A. (2003). The role of transformational leadership in enhancing organizational innovation: Hypotheses and some preliminary findings. The Leadership Quarterly, 14(4), 525-544.

Karadağ, E., Başaran, A. \& Korkmaz, T. (2009). İlköğretim okulu öğretmenlerinin algıladıkları liderlik biçimleri ile iş doyumları arasındaki ilişki. Balıkesir Üniversitesi Sosyal Bilimler Enstitüsü Dergisi, 12(21), $32-45$.

Karasar, N. (2012). Bilimsel Araştırma Yöntemi. Ankara: Bilim Kitap Kırtasiye Yayınevi.

Karataş, S. \& Güleş, H. (2010) İlköğretim okulu öğretenlerinin iş tatmini ile örgütsel bağl1lığı arasındaki ilişki. Uşak Üniversitesi Sosyal Bilimler Dergisi, 3(2), 74-89.

Karip, E. (1998). Dönüşümcü liderlik. Kuram ve Uygulamada Ĕ̆itim Yönetimi 4(4), 1-23.

Kaygın, E. \& Yerdelen Kaygın, C. (2012). Çalışanların dönüştürücü liderlik algılarını belirlemeye yönelik bir araştırma. Organizasyon ve Yönetim Bilimleri Dergisi,4(2), 29-38.

Kiriş, B., Aslan, H. (2019). Okul müdürlerinin dönüşümcü liderlik özellikleri ile öğretmenlerin mesleki benlik saygıları arasındaki ilişkiye yönelik öğretmen algıları. Elektronik Sosyal Bilimler Dergisi, 18(72), 16561675.

Kiriş, İ. (2013). İlkokul müdürlerinin dönüşümcü liderlik özelliklerini gösterme düzeylerine ilişkin öğretmen görüşleri (Unpublished master thesis), Çağ University, Mersin.

Kırkpınar, S., İşcan, ÖF. (2018). Liderlik tarzlarının iş tatmini ve örgütsel bağlı̆lı̆a. Hacettepe Sağllk İdaresi 
Dergisi, 21(1), 65-85

Korku, C. (2018). Sağlık yöneticilerinin dönüşümcü ve otantik liderlik özelliklerinin yenilikçilik iklimine ve yenilikçi iş davranışına etkisi (Unpublished master thesis). Hacettepe University, Ankara.

Kosa, G. (2019). Yöneticilerinin girişimcilik ve inovasyon algılarının incelenmesi: Kobi yöneticileri üzerine bir araştırma. İşletme Araştirmalari Dergisi, 11(3), 1792-1806

Koustelios, A. D. (2001). Personal characteristics and job satisfaction of Greek teachers. International Journal of Educational Management, 15(7), 354-358.

Lan, T., Chang, H., Ma, T., Zhang, L. \& Chuang K. (2019). Influences of transformational leadership, transactional leadership, and patriarchal leadership on job satisfaction of cram school faculty members. Sustainability, 11(12), 1-13.

Ledoux, J.E. (1999). Distinct populations of NMDA receptors at subcortical and cortical inputs to principal cells of the lateral amygdala. Journal of Neurophysiol, 81(2), 930-934.

McCleskey, J. A. (2014). Situational, transformational, and transactional leadership and leadership development. Journal of Business Studies Quarterly, 5(4), 117-130.

Mert, G., Dördüncü, H. \& İncaz, S. (2019). Dönüştürücü liderlik davranışlarının iş tatmini üzerindeki etkisi: Vakıf üniversitesi örneği. Uluslararası Sosyal Araştırmalar Dergisi, 12(65), 1169-1182.

Muchinsky, P.M. (2000). Psychology Applied to Work (Sixth Edition). USA: Wadsworth.

Nödl, B. (2017). The influence of leadership behavior on innovative work behavior: The case of a Pharmaceutical Company in Germany (Unpublished master thesis). University of Twente, Netherlands.

Ocak, M., Güler, M., \& Basım, H. N. (2016). Psikolojik sermayenin örgütsel bağlllık ve iş tatmini tutumları üzerine etkisi: Bosnalı öğretmenler üzerine bir araştırma. Çankırı Karatekin Üniversitesi İktisadi ve İdari Bilimler Fakültesi Dergisi, 6(1), 113-130.

Önhon, O. (2016). Türkiye'de telekomunikasyon sektorunde isyerlerindeki yenilikcilik iklimi ile calısanlarm yenilik yapma davranıslarn arasındaki iliski ve bu iliskiye liderlik algılarmnn etkileri (Unpublished doctorate thesis). Marmara University, İstanbul.

Özbek, A. (2014). Öğretmenlerin yenilikçilik düzeylerinin TPAB yeterlikleri üzerindeki etkisinin incelenmesi (Unpublished master thesis). Necmettin Erbakan University, Konya.

Özgen, H. \& Yalçın. A. (2011). İnsan kaynakları yönetimi stratejik bir yaklaşım. Ankara: Akademisyen Kitapevi.

Özkan, A. (2017). Illkokul ve ortaokul ö̆gretmenlerinin iş doyumu düzeyleri (Unpublished doctorate thesis). Balıkesir University, Balıkesir.

Parzefall, M., Seeck, H., \& Leppänen, A. (2008). Employee innovativeness in organizations: A review of the antecedencts. Finnish Journal of Business Economics, 2(8), 165-182.

Pierce, J. L. \& Delbecq, A. L. (1977). Organization structure, individual attitudes and innovation. Academy of Management Review, 2(1), 27-37.

Şahin, S. (2004). Okul müdürlerinin dönüşümcü ve sürdürümcü liderlik stilleri ile okul kültürü arasındaki ilişkileri (İzmir ili örneği). Kuram ve Uygulamada Eğitim Bilimleri, 4(2), 365- 395.

Şakacı, E. (2019). Psikolojik şiddetin iş doyumu üzerindeki etkisi (Unpublished master thesis). Gazi University, Ankara.

Şanlı, S. \& Akbaş, T. (2009). Adana ilinde çalışan polislerin iş doyumu düzeylerinin bazı değişkenler açısından incelenmesi. Polis Bilimleri Dergisi 11(2), 73-86.

Saraç M. (2019). Öğretmenlerin yenilikçilik düzeylerinin incelenmesi (Unpublished master project). Pamukkale University, Denizli. 
Sarros, J. C., Cooper, B. K. \& Santora, J. C. (2008). Building a climate for innovation through transformational leadership and organizational culture. Journal of Leadership \& Organizational Studies, 15(2), 145-158.

Saruhan, Ş. C. \& Özdemirci, A. (2013). Bilim, felsefe ve metodoloji. İstanbul: Beta Basım.

Scott, S. G., \& Bruce, R. A. (1994). Determinants of innovative behavior: A path model of individual innovation in the workplace. Academy of Management Journal, 37(3), 580-607.

Şeker, B. D. \& Zırhlığlu, G. (2009). Van emniyet müdürlüğü kadrosunda çalışan polislerin tükenmişlik, iş doyumu ve yaşam doyumları arasındaki ilişkilerin değerlendirilmesi. Polis Bilimleri Dergisi, 11(4), 1-26

Şentürk, F. K., Durak, M., Yılmaz, E., Kaban, T., Kök, N. \& Baş, A. (2016). Dönüşümcü ve etkileşimci liderlik tarzlarının bireysel yenilikçiliğe etkisini belirlemeye yönelik bir araştırma. Mehmet Akif Ersoy Üniversitesi Sosyal bilimler Enstitüsü Dergisi, 8(17), 173-198.

Şeren, M. \& Özcan, M. E. (2019). İlk ve ortaokul öğretmenlerinin iş doyumu düzeyleri: Boylamsal analiz. Uluslararası Sosyal Bilimler Dergisi, 3(14), 77-89.

Silah, M. (2002). Sanayi işletmelerinde önemli ve çağdaş bir gereksinim: Süreç danışmanlığı uygulamaları. Çukurova Üniversitesi Sosyal Bilimler Dergisi, 26(1), 143-168.

Şirin, E. F. (2008). Beden eğitimi ve spor yüksekokulu yöneticilerinin liderlik stilleri ve çatışma yönetimi stratejilerinin incelenmesi (Unpublished doctorate thesis). Gazi University, Ankara.

Şirin, Y. E., Aydın, Ö. \& Bilir, F. P. (2018). Transformational-transactional leadership and organizational cynicism perception: Physical education and sport teachers sample. Universal Journal of Educational Research 6(9), 2008-2018.

Smoak, L. M. (2008). Transformational leadership, work- related cultural values and job satisfaction (Unpublished doctoral thesis). Nova Southeastern University, Florida.

Sung, C. (2007). Relationship among supervisor's transformational and transactional leadership styles and teacher's job satisfaction in Taiwan higher education (Doctor of Philosophy). Lynn University,

Tang, Y., Shao, Y. F. \& Chen, Y. J. (2019). Assessing the mediation mechanism of job satisfaction and organizational commitment on innovative behavior: The perspective of psychological capital. Frontiers Psychology, 10, 1-12,

Tanhan, A. (2020). COVID-19 sürecinde online seslifoto (OSF) yöntemiyle biyopsikososyal manevi ve ekonomik meseleleri ve genel iyi oluş düzeyini ele almak: OSF'nin Türkçeye uyarlanması. Turkish Studies, 15(4), 1029-1086.

Taş, A. \& Önder, E. (2010). Yöneticilerin liderlik davranışlarının personel iş doyumuna etkisi. Elektronik Sosyal Bilimler Dergisi, 9(32), 17-30.

Taşdan, M. \& Tiryaki, E. (2008). Özel ve devlet ilköğretim okulu öğretmenlerinin iş doyumu düzeylerinin karşılaştırılması. Ĕ̆itim ve Bilim, 33(147), 54-70.

Taşdan, M. (2008). Kamu ve özel ilköğretim okullarında görevli öğretmenlerin değer, iş doyumu ve öğretmene mesleki sosyal destek ile ilgili görüşleri (Unpublished doctorate thesis). Ankara University, Ankara

Tengilimoğlu, D. (2005). Hizmet işletmelerinde liderlik davranışları ile iş doyumu arasındaki ilişkinin belirlenmesine yönelik bir araştırma. Ticaret ve Turizm Eğitim Fakültesi Dergisi, 1, $23-45$.

Thurlings, M., Evers, A. T., \& Vermeulen, M. (2015). Toward a model of explaining teachers' innovative behavior: A literature review. Review of Educational Research, 85(3), 430-471.

Unsworth, K. L. \& Parker, S. K. (2003), Proactivity and innovation: promoting a new workforce for the new workplace, in Holman, T., Wall, T. D., Clegg, C. W., Sparrow, P. and Howard, A. (Eds), The New Workplace: A Guide to the Human Impact of Modern Work Practices, (pp. 175-96). Chichester: Wiley. 
Vaccaro, I. G., Jansen, J. J., Van Den Bosch, F. A. \& Volberda, H. W. (2012), Management innovation and leadership: The moderating role of organizational size. Journal of Management Studies, 49(1), 28-51.

Van de Ven, A. (1986). Central problems in the management of innovation. Management Science, 32, 590-607.

Yapıc1, İ. Ü. \& Kaya, S. (2020). Biyoloji öğretmenlerinin bireysel yenilikçilik düzeylerinin incelenmesi (Diyarbakır ili örneği). Elektronik Sosyal Bilimler Dergisi, 19(73), 348-362.

Yeğin, M. (2009). İdari personelin iş doyumu üzerine bir araştırma: Dokuz eylül üniversitesi tıp fakültesi (Unpublished master thesis). Dokuz Eylül University, İzmir.

Yelboğa, A. (2007). Bireysel demografik değişkenlerin iş doyumu ile ilişkisinin finans sektöründe incelenmesi. Sosyal Bilimler Dergisi, 4(2), 1-18.

Yılmaz, R. \& Yüksel Şahin, F. (2016). Yöneticilerin dönüştürücü liderlik düzeylerinin psikolojik iyi oluş ve bazı kişisel değişkenlere göre yordanması. Gazi Üniversitesi Gazi Ĕ̆itim Fakültesi Dergisi, 36(3), 595-615. 